\title{
Clinical features and outcome of preseptal and orbital cellulitis in hospitalized children: Four years experience
}

\author{
Hastanede yatan çocuklarda preseptal ve orbital selülitin klinik \\ özellikleri ve seyri: Dört yıllık tecrübe
}

\author{
Sevliya ÖCAL DEMiR, Eren ÇAĞAN, Eda KEPENEKLI KADAYIFCI, Ayşe KARAASLAN, Serkan ATICI, Gülşen AKKOÇ, \\ Nurhayat YAKUT, Ahmet SOYSAL
}

\begin{abstract}
Preseptal and orbital cellulitis are relatively more common in children than adults. If left untreated orbital cellulitis is more serious, and can cause vision loss and life-threatening conditions. Thus, it's early differentiation from preseptal cellulitis is critical for initiating prompt treatment. In this study, contrasting features of preseptal and orbital cellulitis are highlighted to aid physicians in the management of these infections. Medical records of 62 children admitted to hospital with the diagnosis of preseptal or orbital cellulitis between January 2011 to July 2015 were retrospectively evaluated. In this series, preseptal cellulitis (81\%) was observed more commonly than orbital cellulitis (19\%). The average age of the patients with orbital cellulitis was higher than that of the cases with preseptal cellulitis (8.1 \pm 4 v.s $4.8 \pm 3$ years, $p=0.009)$. Ophthalmoplegia and proptosis were observed in the $58 \%$ of the patients with orbital cellulitis. Sinusitis was the most common predisposing factor. Orbital magnetic resonance imaging (MRI) revealed subperiostal abscesses in three cases who were previously diagnosed as preseptal cellulitis by orbital computerized tomography (CT). Antibiotherapy with ampicillinsulbactam with or without ceftriaxone was successful in $95.2 \%$ of the patients. The longer treatment period was required for orbital cellulitis when compared to preseptal cellulitis (median duration of 14 vs 29 total antibiotic days, respectively, $p<0.001$ ). Sinus abscess drainage was needed in two cases of orbital cellulitis and abscess drainage in one case of preseptal cellulitis. During follow-up, any serious complications were not observed. Accurate diagnosis and prompt treatment of orbital cellulitis can prevent its serious complications, MRI can aid in difficult cases so as to differentiate orbital cellulitis from preseptal cellulitis.
\end{abstract}

Keywords: Orbital, preseptal, cellulitis, imaging

Anahtar kelimeler: Orbital, preseptal, görüntüleme, selülit
Preseptal ve orbital selülit çocuklarda erişkinlere kıyasla sık görülmektedir. Orbital selülit tedavisiz bırakıldığında görme kaybı veya yaşamı tehdit eden durumlarla sonuçlanabilen daha ciddi bir enfeksiyondur, preseptal selülitten erken ayırt edilmesi doğru yaklaşım ve tedavinin bir an önce başlatılması açısından kritiktir. Bu çalışmada, preseptal ve orbital selülitin ayırt edici özellikleri vurgulanarak hekimin ayırıc tanıyı erken yapmasına yardımcı olmak amaçlandı. Ocak 2011 ve Haziran 2015 tarihleri arasında hastaneye preseptal veya orbital selülit tanısı ile yatırılan 62 çocuğun tıbbi kayıtları retrospektif olarak incelendi. Bu seride preseptal sellülit (\%81) orbital selülite (\%19) kıyasla daha sıktı. Orbital selülitli olgularda ortalama yaş preseptal selülitli olgulara göre daha büyüktü $(8,1 \pm 4$ 'e karşın $4.8 \pm 3$ yıl, $p=0,009)$. Orbital selülitli olguların \%58'inde oftalmopleji ve proptozis görüldü. En sık predispozan faktör sinüzitti. Daha önce bilgisayarlı tomografi ile preseptal selülit tanısı alan üç olguda manyetik rezonans görüntüleme subperiostal apseler olduğunu gösterdi. Ampisilinsulbaktam tek başına veya seftriakson ile beraber verildi, hastaların \%95,2'sinde başarılı oldu. Orbital selülitte daha uzun süreli tedavi gerekti (ortalama 14 güne karşın, 29 toplam antibiyotik günü $p<0,001)$. Iki orbital selülit olgusunda sinüs drenajı, bir preseptal selülit olgusunda apse drenajı gerekti. Hastaların ayaktan takibinde herhangi bir komplikasyon gözlenmedi. Orbital selülitin erken tanısı ve doğru tedavisi ağır komplikasyonların gelişmesini önler, orbital selülitin preseptal selülitten ayırt edilmesinde klinik bulgular yetersiz olduğunda kontrastlı orbital MRI yardımcı olabilir.

\section{INTRODUCTION}

Preseptal and orbital cellulitis are much more com- mon in young children than older ones and adults. In addition, preseptal cellulitis is more frequent than orbital cellulitis ${ }^{1,2}$. Preseptal cellulitis is an infection

Received: 17.01 .2017

Accepted: 03.03.2017

Marmara University School of Medicine, Department of Pediatrics, Division of Pediatric Infection Disease, Istanbul, Turkey

Yazışma adresi: Sevliya Öcal Demir, Marmara University School of Medicine, Department of Pediatrics, Division of Pediatric Infection Disease, Istanbul, Turkey

e-mail: sevliyademir@gmail.com 
involving anterior portion of the orbital septum, whereas orbital cellulitis involves ocular adnexal structures posterior to the orbital septum. Orbital cellulitis is more serious. It can lead to blindness by causing occlusion of central retinal artery or vein, or by damaging the optic nerve. Other serious complications of orbital cellulitis are endophthalmitis, cavernous sinus thrombosis, meningitis, intracranial abscesses, and even death that generally results from the delay in the diagnosis and initiation of appropriate treatment $^{3}$.

Although preseptal and orbital cellulitis yield different clinical outcomes, initial symptoms such as pain, eyelid swelling and erythema are the mutual presenting symptoms. For this reason, the clinical differentiation of these two conditions can be initially difficult. If thorough history taking and physical examination including an ophthalmological evaluation could not help to differentiate difficult cases from advanced disease, contrast-enhanced computed tomography (CT) or magnetic resonance imagining (MRI) scanning can aid in differential diagnosis.

Here we used our experiences to characterize features of orbital and preseptal cellulitis in order to make a differentiation between them, and aimed to highlight importance of early diagnosis and treatment of orbital cellulitis.

\section{MATERIAL and METHODS}

The study was performed in Marmara University Training and Research Hospital in Istanbul, Turkey. In this retrospective study, data were collected by reviewing medical records of all admissions for preseptal and orbital cellulitis in children below 18 years of age who were referred to us between January 2011 and July 2015. Data regarding clinical diagnosis, age, gender, predisposing factors, clinical manifestations, laboratory and radiological data, antibiotic treatment, surgical procedure, length of hospital stay and complications were recorded. Local Ethics Committee approval was obtained for this study.
Diagnosis of preseptal and orbital cellulitis was made according to recorded clinical findings. Hyperemia, tenderness and swelling of periorbital tissues were accepted as undifferentiating features, whereas chemosis, proptosis, limitation of extraocular movements of eyes, pain with eye movement are accepted as peculiar signs of orbital cellulitis. Radiological investigation was performed for the diagnosis of 60 cases with contrast- enhanced orbital MRI and/or CT. Daily ophthalmological examination had been made for patients with orbital cellulitis until regression of abscesses was demonstrated on control orbital MRI. Laboratory investigations including complete blood count (CBC), C-reactive protein (CRP) levels, blood cultures were assessed, and antibiotherapy regimens were also noted.

Statistical analyses were performed with NCSS (Number Cruncher Statistical System) 2007 (Kaysville, Utah, USA). When data were analyzed beside descriptive statistical methods (mean, standard deviation, median, frequency, rate, minimum, maximum), for the comparison of two groups of parameters that are not normally distributed, Mann-Whitney $U$ test was used. For the comparison of qualitative data Fisher-Freeman-Halton test, Fisher's exact test, and Yates' Correction Continuity test (Yates' corrected chi-square) was used. Levels of significance were set at $p<0.01$ and $p<0.05$.

\section{RESULTS}

A total of 62 children with preseptal cellulitis $(n=50$; $81 \%$ ) or orbital cellulitis ( $n=12 ; 19 \%)$ were identified and included in this study. Mean ages (mean \pm standard deviation [SD]) of the patients with orbital and preseptal cellulitis were $8.1 \pm 4$ and $4.8 \pm 3$ years, respectively $(p=0.009)$. Presentation of orbital cellulitis was in the fall or winter for six cases $(n=6 ; 50 \%)$, in the spring or summer for other six cases $(n=6 ; 50 \%)$, whereas the most of cases with preseptal cellulitis were seen in the spring or summer(70\%). Eye involvement was seen in 59 cases (95.2\%). Bilateral involvement was noted only in three cases with preseptal cellulitis and conjunctivitis. Baseline symptoms of all 
cases were hyperemia, tenderness and swelling of periorbital tissues. In the orbital cellulitis group seven cases (58.3\%) had ophthalmoplegia $(p=0.001)$, three of them also had proptosis $(p=0.035)$ (Figure 1). Sinusitis effected ten cases (83.3\%) with orbital cellulitis, and nine cases (18\%) with preseptal celluli-

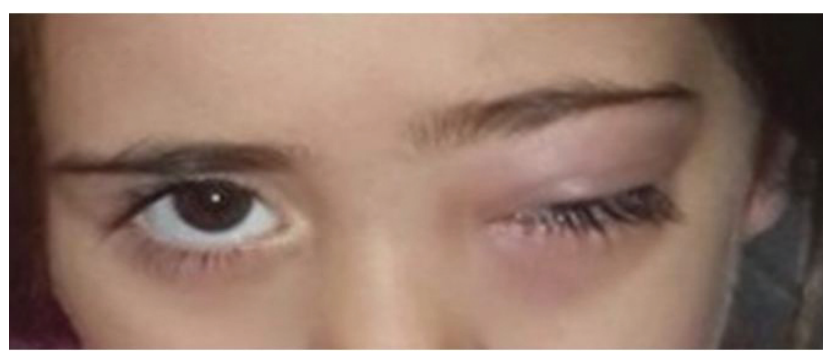

Figure 1. A case of orbital cellulitis with proptosis. tis $(p<0.001)$. Other predisposing factors include conjunctivitis, dental abscesses, varicella zoster infection, herpes simplex virus infection of adjacent skin, insect bite were recorded only in the preseptal cellulitis group (Figure 2). Demographic characteristics of the patients were summarized in Table 1.

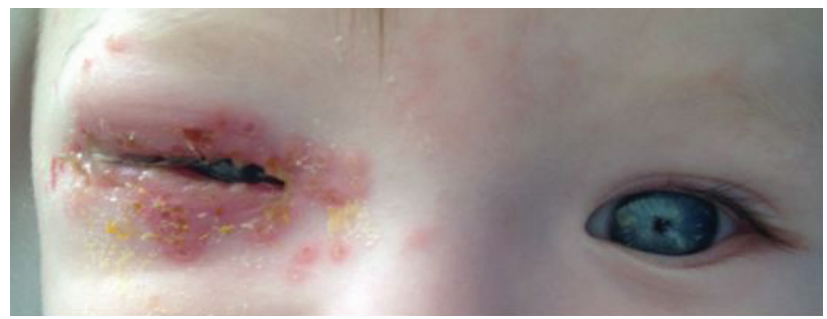

Figure 2. A case of preseptal cellulitis with herpetic lesion.

Table 1. Demographic characteristics of preseptal and orbital cellulitis.

\begin{tabular}{|c|c|c|c|c|c|}
\hline \multicolumn{2}{|l|}{ Cellulitis } & \multirow{2}{*}{$\begin{array}{l}\text { Total } \\
32(51.6)\end{array}$} & \multirow{2}{*}{$\begin{array}{l}\text { Orbital } \\
8 \text { (66.7) }\end{array}$} & \multirow{2}{*}{$\begin{array}{l}\text { Preseptal } \\
24(48)\end{array}$} & \multirow{2}{*}{$\begin{array}{l}\mathbf{P} \\
{ }^{\mathrm{a}} 0.401\end{array}$} \\
\hline Gender n (\%) & Male n (\%) & & & & \\
\hline \multirow{3}{*}{ Age (median, years) } & Female $\mathrm{n}(\%)$ & $30(48.4)$ & $4(33.3)$ & $26(52)$ & \\
\hline & mean $\pm S D$ & $5.43 \pm 3.59$ & $8.13 \pm 4.26$ & $4.79 \pm 3.13$ & ${ }^{\mathrm{d}} 0.009 * *$ \\
\hline & $\begin{array}{l}\text { Min-Max } \\
\text { (Median) }\end{array}$ & $0.25-16(5)$ & $3-15(7.75)$ & $0.25-16(4.25)$ & \\
\hline \multicolumn{6}{|l|}{ Predisposing factos } \\
\hline & Sinusitis n (\%) & $19(30.6)$ & $10(83.3)$ & $9(18.0)$ & ${ }^{\mathrm{b}} 0.001 * *$ \\
\hline & Conjunctivitis n (\%) & $8(12.9)$ & $1(8.3)$ & $7(14.0) 8$ & ${ }^{\mathrm{b}} 1.000$ \\
\hline & Dental abscesses n (\%) & $5(8.1)$ & - & $5(10.0)$ & b 0.573 \\
\hline & $\begin{array}{l}\text { Herpes simplex virus } \\
\text { infection } \mathrm{n}(\%)\end{array}$ & $2(3.2)$ & - & $2(4.0)$ & b1.000 \\
\hline & $\begin{array}{l}\text { Varicella zoster infection } \\
\mathrm{n}(\%)\end{array}$ & $2(3.2)$ & - & $2(4.0)$ & b1.000 \\
\hline & Insect-bite n (\%) & $1(1.6)$ & - & $1(2.0)$ & ${ }^{b} 1.000$ \\
\hline \multicolumn{6}{|l|}{ Laboratory findings } \\
\hline \multirow[t]{3}{*}{ White blood count (WBC) } & mean $\pm S D$ & $12761.13 \pm 4867.46$ & $14483.33 \pm 5816.25$ & $12347.80 \pm 4582.52$ & ${ }^{\mathrm{d}} 0.084$ \\
\hline & Min-Max & $800-23400$ & $800-22800$ & $3900-23400$ & \\
\hline & (Median) & $(12300)$ & $(13550)$ & $(11000)$ & \\
\hline \multirow[t]{3}{*}{ Absolute neutrophil count (ANC) } & mean $\pm S D$ & $8080.65 \pm 4776.85$ & $11183.33 \pm 5058.90$ & $7336.00 \pm 4442.73$ & ${ }^{\mathrm{d}} 0.006 * *$ \\
\hline & Min-Max & $100-21400$ & $200-17900$ & $100-21400$ & \\
\hline & (Median) & $(6950)$ & $(10500)$ & $(6600)$ & \\
\hline \multirow[t]{3}{*}{ C-reactive protein (CRP) } & mean $\pm S D$ & $39.79 \pm 66.22$ & $69.99 \pm 78.18$ & $32.54 \pm 61.72$ & ${ }^{\mathrm{d}} 0.020 *$ \\
\hline & Min-Max & $0,4-393$ & $1-247$ & $0.4-393$ & \\
\hline & (Median) & $(17.45)$ & (37) & $(13.5)$ & \\
\hline Surgical therapy $\mathrm{n}(\%)$ & & $3(4.8)$ & $2(16.7)$ & $1(2.0)$ & b0.093 \\
\hline \multirow[t]{3}{*}{ Total antibiotic days } & mean $\pm S D$ & $17.82 \pm 9.82$ & $30.08 \pm 12.74$ & $14.88 \pm 6.16$ & ${ }^{\mathrm{d}} 0.001 * *$ \\
\hline & Min-Max & $6-49$ & $10-49$ & $6-35$ & \\
\hline & (Median) & (15) & $(28.5)$ & $(14)$ & \\
\hline \multirow[t]{3}{*}{ Hospitalization days } & mean $\pm S D$ & $9.31 \pm 6.14$ & $19.42 \pm 6.44$ & $6.88 \pm 2.55$ & ${ }^{\mathrm{d}} 0.001 * *$ \\
\hline & Min-Max & $3-35$ & $10-35$ & $3-14$ & \\
\hline & (Median) & (7) & (20.5) & (7) & \\
\hline
\end{tabular}

${ }^{a}$ Yates' Continuity Correction, ${ }^{b}$ Fisher Exact Test, ${ }^{c}$ Fisher Freeman Halton Test, ${ }^{d}$ Mann Whitney $\cup$ Test, $* * p<0.01,{ }^{*} p<0.05$ 
Mean white blood cell counts of the patients with orbital cellulitis and preseptal cellulitis were $14483 \pm 5816 / \mathrm{mm}^{3}$ and $12347 \pm 4582 / \mathrm{mm}^{3}$, respectively $(p=0.084)$. On the other hand, mean absolute neutrophil count was significantly higher in the orbital cellulitis group, than in the preseptal group $\left[11183 \pm 5058 / \mathrm{mm}^{3}\right.$ and $7336 \pm 4442 / \mathrm{mm}^{3}$ respectively, $(p=0.006)]$. Similarly, median CRP value was significantly higher in the orbital cellulitis group than preseptal cellulitis group [37 mg/L (range:1-247 mg/ L) v.s. $13.5 \mathrm{mg} / \mathrm{L}$ (range: 0,4-393 $\mathrm{mg} / \mathrm{L}$ ), respectively $(p=0.020)$ ] (Table 1$)$.

For diagnosis beside clinical assessment, contrast enhanced orbital MRI and/or CT were used in 60 cases. In 13 cases with preseptal cellulitis, because of inadequate response to treatment, or if their cranial CT obtained without contrast or with low quality, contrast enhanced orbital MRI was performed. Of those orbital cellulitis with subperiostal abscess were detected in three patients (Figure 3).

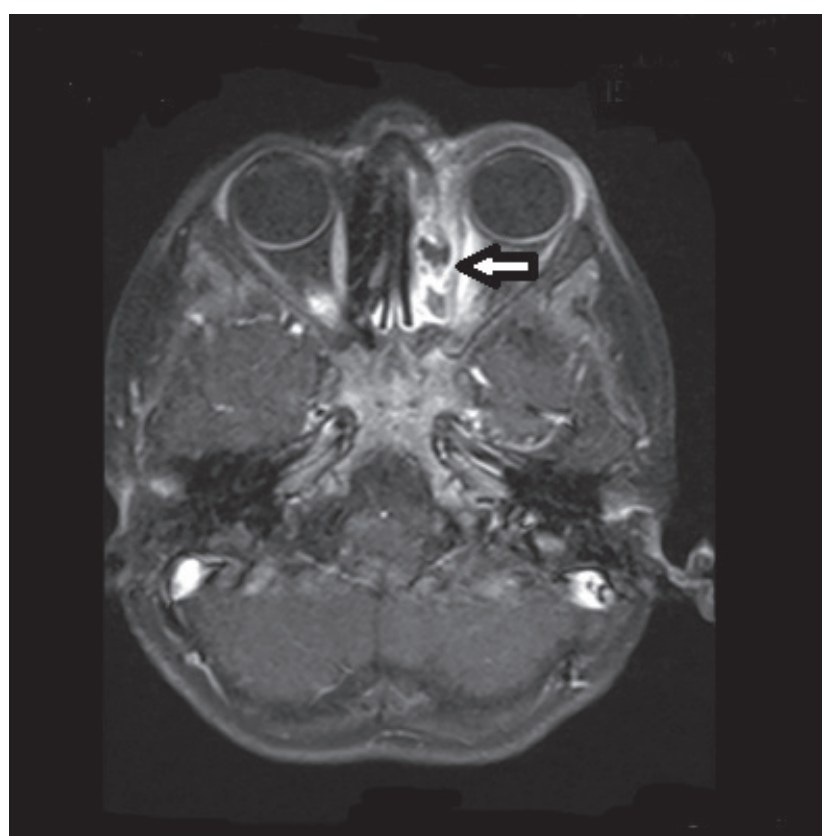

Figure 3. Orbital MR of same case in figure 1, arrow show subperiostal abscesses.

Blood cultures were taken from 36 of 62 cases, and only $4(\% 11)$ of them were positive. Methicillinsensitive Staphylococcus aureus (MSSA) was isolated in 2, Streptococcus pyogenes in one, methicillin- resistant Staphylococcus epidermidis (MRSE) in one patient. Three of four positive cultures were obtained from the patients in the orbital celulitis group. The cultures of sinus drainage material remained sterile, all three cases had previously used antibiotherapy.

Ampicillin-sulbactam $(n=35)$ and ampicillinsulbactam plus ceftriaxone $(n=27)$ were the most preferred treatment options. In three cases with orbital cellulitis; clinical response to treatment was deemed to be insufficient since high fever, elevated acute phase reactants and widening of periorbital tissue swelling persisted over three days of treatment. So antibiotherapy regimens were revised for each patient. Vancomycin+cefoperazonesulbactam $(n=1)$, vancomycin+meropenem $(n=1)$ and vancomycin+piperacillin-tazobactam $(n=1)$ were used, so cure achieved. In four cases, acyclovir was added to antibacterial treatment for infection of adjacent skin with varicella zoster or herpes simplex virus. In three cases, surgical intervention, abscess drainage was required. Median duration of oral plus intravenous antibiotic use for orbital cellulitis and preseptal cellulitis were 28.5 days (range: 10-49 days) and 14 days (range: 6-35 days), respectively $(p<0.001)$. Median length of hospital stay was 20.5 days (range: 10-35 days) for orbital cellulitis and 7 days (range: 3-14 days) for preseptal cellulitis $(p<0.001)$. No serious complication was observed during the hospital stay and six months after discharge.

\section{DISCUSSION}

Soft tissue infections around the eye globe are common and usually benign in nature. Hovewer, orbital cellulitis which may be missed during the initial evaluation of the patients can be severe and complicated. Despite the fact that our study included limited number of children, evaluation of these cases are important to stress major differences between milder (preseptal) and the more serious form of the disease (orbital cellulitis). By this way, the consequences of late diagnosis can be prevented and the proper treatment can be initiated. 
In this study relative frequency of orbital cellulitis among infections involving in and around eye globe was similar to those reported in previous studies $(4 \% \text { to } 28 \%)^{4-6}$. Mean age of the children with orbital and preseptal cellulitis in our study was compatible to the literature data, that the mean age of children with orbital cellulitis is greater than that of children with preseptal cellulitis ${ }^{7}$. This finding may reflect the sequential maturation of the sinuses, since infection of sinuses is the major predisposing factor for orbital cellulitis. Ethmoid sinus, the most involved sinus in orbital cellulitis, is present at birth and has a rapid growth phase between 3 and 8 years of age while maxillary sinus has rapid growth between 7 and 12 years of age ${ }^{8}$.

As well-known, sinusitis is the most important predisposing factor for preseptal and orbital cellulitis. Orbital cellulitis almost always occurs as a complication of sinusitis with extension of the infection into the orbit. In the study of Botting et al, $91 \%$ of 35 cases of orbital celulitis had acute sinusitis at diagnosis ${ }^{1}$. Ethmoid sinus was demonstrated as the main source of the orbital infections in other reports ${ }^{2,9}$. In our study, sinusitis was associated with $83.3 \%$, and $18 \%$ of the patients with orbital, and preseptal cellulitis, respectively. Dental abscesses, conjunctivitis, varicella zoster and herpes simplex virus infection of the adjacent skin, and insect-bite were other predisposing factors for preseptal cellulitis which may be associated with broken skin barrier. Similar to other series, the number of our patients with preseptal cellulitis reached the peak incidence during spring and summer ${ }^{6,10}$. This is assumed to be due to predisposing factors such as insect bite and conjunctivitis which are common in these seasons.

Hyperemia, tenderness and swelling of periorbital tissues are symptoms of preseptal cellulitis. But when the treatment is delayed, infection can spread to the posterior part of the orbital septum. Chemosis, proptosis, pain with eye movement, decreased visual acuity, and limitation of eye movements are known as predictors for orbital cellulitis although these symptoms are not seen uniformly in all cases. Rudloe et al reported that $50.5 \%$ of 35 cases with orbital cellulitis did not experience these symptoms ${ }^{11}$. Similarly, our seven $(58.3 \%)$ cases with orbital cellulitis had ophthalmoplegia, and three of them (25\%) also had proptosis. In the remaining 5 patients, diagnoses were actually based on radiological appeareance. Since our patients were children, the expression of painful eye movements may be underestimated. Daily ophthalmological examination was made for patients with orbital cellulitis during hospitalization but none of them had problems with vision acuity.

Similar to previous data, though not statistically significant, mean white blood cell count was higher in the orbital cellulitis group which did not aid in the diagnosis ${ }^{9}$. Hovewer, the absolute neutrophil count and median CRP level were statistically significantly elevated in orbital cellulitis .

In our study, contrast-enhanced orbital MRI was found to be more sensitive than CT to make a differentiation between orbital and preseptal cellulitis. Hovewer, since these two methods were not compared with controlled studies, clinical experience of our radiologists estalished the diagnoses of orbital and preseptal cellulitis. Magnetic resonance imaging is especially recommended for tracking the progression of soft tissue disease and it is also preferred to save pediatric patients from the side effects of radiation exposure ${ }^{12}$. But in young children it may require sedation. Guidelines from United Kingdom describe indications for radiologic imaging with $\mathrm{CT}$ as follows: inability to evaluate vision; ophthalmoplegia, proptosis, bilateral edema or worsening visual acuity; no improvement after 24 hours of administration of intravenous antibiotics; fever not resolved within 36 hours; or evidence of central nervous system involvement ${ }^{13}$.

Blood cultures were positive in four cases for MSSA, S. pyogenes, and MRSE. According to the reports of previous studies Staphylococcus aureus, Haemophylus influenzae type b (Hib), and Streptococcus species are the most common organisms in preseptal and 
orbital cellulitis ${ }^{14}$. Because of widespread vaccination against Hib; Staphylococcus aureus and Streptococcus species account for $75 \%$ of etiologic agents of periorbital infections ${ }^{15}$. On the other hand, MSSA, MRSA and even some streptococcus species constitute the skin flora which can not be differentiated from contaminants. Despite the low rate of positivity, obtaining blood culture is recommended before antibiotic treatment.

As is known, the main indications for surgical intervention are poor response to antibiotic treatment, evidence of an abscess $>10 \mathrm{~mm}$ in diameter, visual impairment and to intracranial spread of the infection ${ }^{17,18}$. Because of the effectiveness of antibacterial therapy, only three cases required surgical intervention. Mortality rate of orbital cellulitis was reported as $17 \%$ which was associated with blindness before the antibiotic era ${ }^{19}$. Nowadays, orbital cellulitis results in loss of vision, and death in 3-11, and 1-2 $\%$ of the patients, respectively ${ }^{20}$.

As expected, median duration of antibiotic use and length of hospital stay for orbital cellulitis were longer than preseptal sellulitis. This is because of clinical and laboratory response were slow in orbital cellulitis. We also prefered of intravenous treatment and close follow-up in hospital with daily ophthalmological examination for orbital cellulitis. Sinus drainage was performed in two patients with orbital cellulitis and they treated with vancomycin+meropenem and vancomycin+piperacillin-tazobactam. Drainage of the abscesses was required in one patient with preseptal cellulitis. No other serious complication was observed during the hospital stay and outpatient control.

\section{CONCLUSION}

Major limitations of our study is its the retrospective design and relatively small number of cases. Nevertheless, we can conclude that both preseptal and orbital cellulitis can be prevented by timely treatment of sinusitis with appropriate antibiotic. In cases where clinical differentiation of orbital and preseptal cellulitis is difficult, or in condition of delayed response to treatment in complicated cases, radiologic imaging with contrast induced MRI can be good choice.

\section{REFERENCES}

1. Botting AM, Mclntosh D, Mahadevan M. Paediatric pre- and post-septal peri-orbital infections are different diseases. A retrospective review of 262 cases. Int J Pediatr Otorhinolaryngol 2008;72:377-83.

https://doi.org/10.1016/j.ijporl.2007.11.013

2. Ambati BK, Ambati J, Azar N, Stratton L, Schmidt EV. Periorbital and orbital cellulitis before and after the advent of Haemophilusinfluenzae type B vaccination. Ophthalmology 2000;107:1450-3.

https://doi.org/10.1016/S0161-6420(00)00178-0

3. Kloek CE, Rubin PA. Role of inflammation in orbital cellulitis. Int Ophthalmol Clin 2006;46:57-68.

https://doi.org/10.1097/00004397-200604620-00007

4. Uzcategui N, Warman R, Smith A, Howard CW. Clinical practice guidlines for managment of orbital cellulitis. J Pediatr Ophthalmol Strabismus 1998;35:73-9.

5. Spires JR, Smith RJ. Bacterial infections in orbital and periorbital soft-tissues in children. Larynoscope 1986;96:763-7. https://doi.org/10.1288/00005537-198607000-00012

6. Georgakopoulos CD, Eliopoulou MI, Stasinos S, Exarchou A, Pharmakakis N, Varvarigou A. Periorbital and orbital cellulitis: a 10-year review of hospitalized children. E J Opthalmol 2010;20:1066-72.

7. Israele V, Nelson JD. Periorbital and orbital cellulitis. J Pediatr Infect Dis 1987;6:404-10. https://doi.org/10.1097/00006454-198704000-00012

8. Shah RK, Dhingra JK, Carter BL, Rebeiz EE. Paranasal sinus development: radyological study. Laryngoscope 2003;113:205-9.

https://doi.org/10.1097/00005537-200302000-00002

9. Ruttum MS, Ogawa G. Adenovirus conjunctivitis mimics preseptal and orbital cellulitis in young children. Pediatr Infect Dis J 1996;15:266. https://doi.org/10.1097/00006454-199603000-00019

10. Jackson K, Baker SR. Clinical implications of orbital cellulitis. Laryngoscope 1986;96:568-74.

https://doi.org/10.1288/00005537-198605000-00018

11. Eustis HS, Mafee MF, Walton C, Mondonca J. MR imaging and CT of orbital infections and complications in acute rhinosinusitis. Radiol Clin North Am 1998;36:1165.

https://doi.org/10.1016/S0033-8389(05)70238-4

12. Antonia GA, Grundfast KM. Periorbital cellulitis. Int J Pediatr Otorhinolaryngol 1987;13:273-8.

https://doi.org/10.1016/0165-5876(87)90108-X

13. Rudloe TF, Harper BM, Prabhu SP, Rahbar R, Vanderveen D, Kimia AA. Acute periorbital infections, who needs emergent imaging? Pediatrics 2010;125:719-26. https://doi.org/10.1542/peds.2009-1709

14. Howel L, Jones NS. Guidelines for the managment of periorbital cellulitis/abscess. Clin Otolaryngol Allied Sci 2004;29:725-8.

https://doi.org/10.1111/j.1365-2273.2004.00889.x

15. Nageswaran S, Woods CR, Benjamin DK Jr, Givner LB, Shetty AK. Orbital cellulitis in children. Pediatr Infect Dis J 
S. Öcal Demir ve ark., Clinical features and outcome of preseptal and orbital cellulitis in hospitalized children: Four years experience

2006;25:695-9.

https://doi.org/10.1097/01.inf.0000227820.36036.f1

16. Devrim I, Kanra G, Kara A, Cengiz AB, Orhan M. Preseptal and orbital cellulitis: 15-year experience with sulbactamampicillin treatment. Turk J Pediatr 2008;50:214-8.

17. Givner LB. Periorbital versus orbital cellulitis. Pediatr Infect Dis J 2002;21:1157.

https://doi.org/10.1097/00006454-200212000-00014
18. Nelson LB, Olitsky SE. Disorders of the orbit. In: Harley's Pediatric Ophthalmology, Lippincott Williams and Wilkins. Philadelphia 2005; p.389.

19. Gamble RC. Acute inflamation of the orbit in children. Arch Ophthalmol 1993;10:483-97. https://doi.org/10.1001/archopht.1933.00830050059008

20. Osguthorpe JD, Hochman M. Inflammatory sinus diseases affecting the orbit. Otolaryngol Clin North Am 1993;26:657. 